\title{
Lethal Complications of the Ehlers-Danlos Syndrome
}

\author{
P. BEIGHTON,* M.R.C.P., M.R.C.P.ED., D.C.H., D.T.M.\&H.
}

\begin{abstract}
Summary: Death from arterial bleeding or gastrointestinal perforation has previously been reported in more than 15 patients with the Ehlers-Danlos syndrome. On a basis of 100 personally examined patients and a review of published accounts, these events seem particularly likely to occur in two distinct and recognizable forms (the gravis and the ecchymotic forms) of the syndrome.
\end{abstract}

\section{Introduction}

The main characteristics of the Ehlers-Danlos syndrome are hyperextensibility of the skin, hypermobility of the joints, and a tendency of the skin to split on minor trauma. The bony prominences are often covered with wide scars, and calcified spheroids may be palpated in the subcutaneous tissues. Musculoskeletal deformities are often encountered, and ocular, cardiovascular, and gastrointestinal abnormalities occur.

Though the Ehlers-Danlos syndrome is uncommon, several reports of death from arterial or gastrointestinal catastrophes

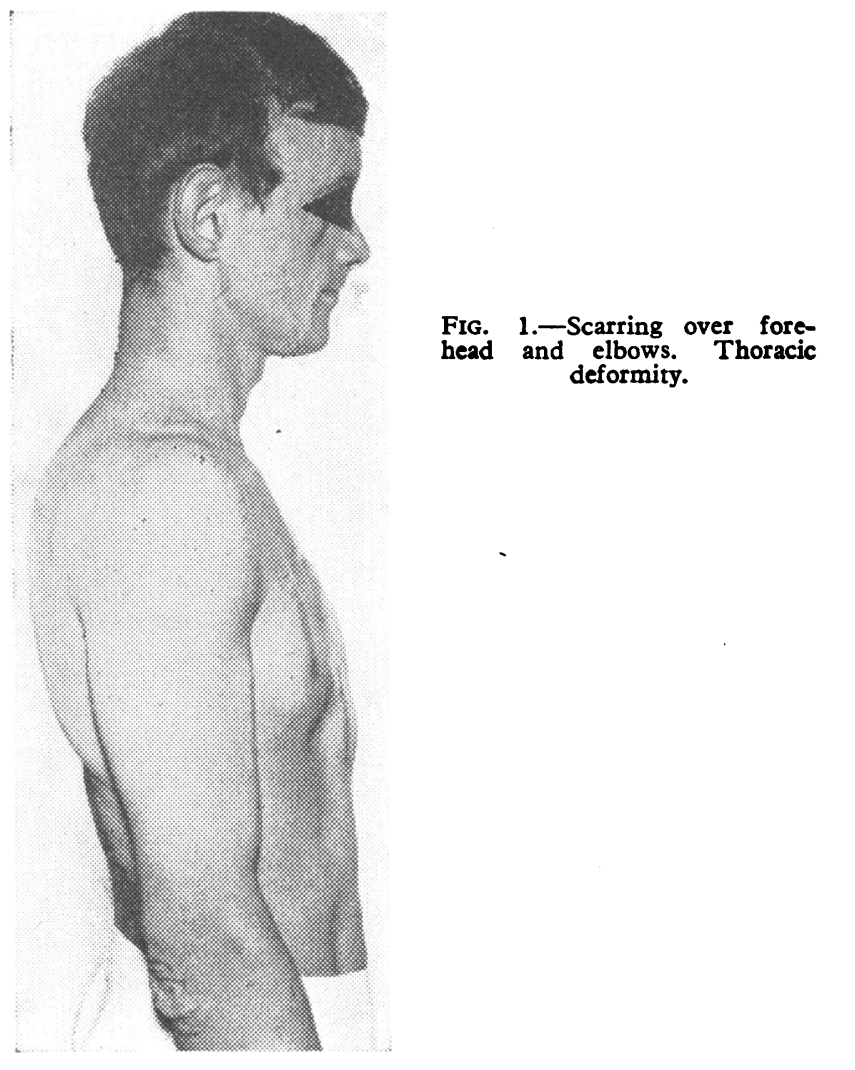

have been published. McKusick (1966) postulated that the condition might be heterogeneous, and Barabas (1967) described three clinical types. The latter suggested that two of his patients had a form of the syndrome in which vascular accidents occurred with great frequency.

* Medical Registrar, St. Thomas's Hospital, London S.E.1. Present address: Johns Hopkins Hospital, Baltimore, U.S.A.
As the Ehlers-Danlos syndrome is familial, the identification of a lethal variety of it would be of great importance from the point of view of management and prognostication.

Recently 100 patients with Ehlers-Danlos syndrome have been examined, and information has been gathered concerning 40 others. The purpose of this paper is to describe the serious cardiovascular and gastrointestinal emergencies that occurred in these patients, and to correlate these events with the patient's clinical stigmata, in an attempt to delineate the group of subjects who are at risk. Comparison is made with all the similar case reports that could be found in the world literature.

\section{Present Investigation}

The 100 patients who were examined were members of 51 kindreds, and could be divided, on a basis of their clinical features, into five groups (Beighton, 1968). The majority did not experience serious disability, but a risk of cardiovascular or gastrointestinal accidents seemed to exist in patients with two particular types of the condition.

The first group had the gravis form of Ehlers-Danlos syndrome, while the second had the ecchymotic variety. These entities possibly correspond to the classical and arterial types described by Barabas (1967).

The gravis form of Ehlers-Danlos syndrome is typified by generalized joint hypermobility, gross skin hyperextensibility, and severe scarring (Figs. 1, 2, and 3). Orthopaedic complications, herniae, and varicose veins are frequently present, and many of these patients are born prematurely.

Thirty-two of those in the series had this type of EhlersDanlos syndrome, and several of them had experienced vascular trouble. Three had spent periods in hospital with huge haematomata which had occurred on minor trauma, while two had arterial bleeding after minor operations. Two other patients with vascular complications are described below (Cases I and II) to illustrate the characteristic features of the gravis form of Ehlers-Danlos syndrome.

The patients with the ecchymotic type have very different stigmata. Their bruising tendency is pronounced and skin

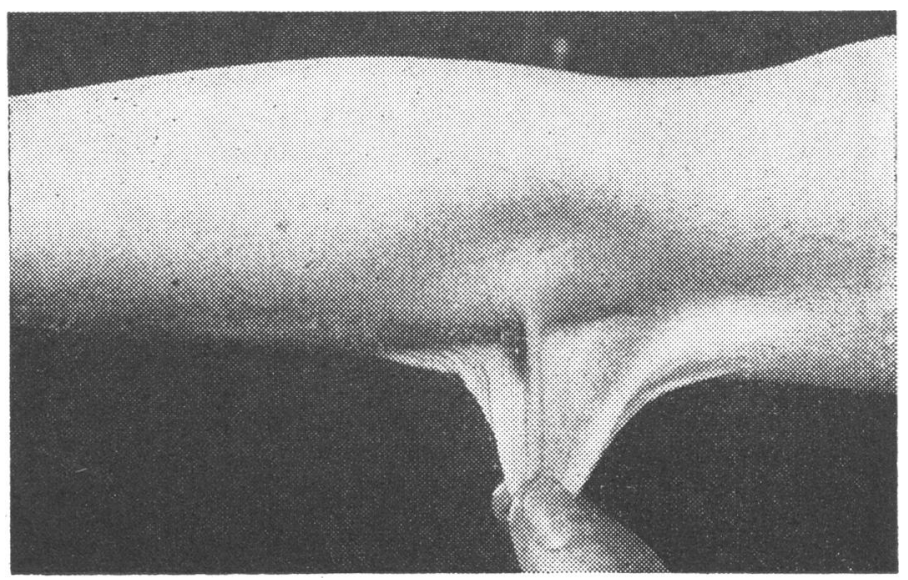

Fig. 2.-Hyperextensibility of the skin. 
splitting occurs, but joint hypermobility is limited to the digits, and the skin is not hyperextensible. Scars are usually atrophic and darkly pigmented (Fig. 4). These patients seem to be particularly liable to vascular incidents. This variety of EhlersDanlos syndrome is uncommon, there being only four instances in the series, though a fifth (Case IV) was reported to me after her death. To illustrate this form of Ehlers-Danlos syndrome two cases are described below (Nos. III and IV).

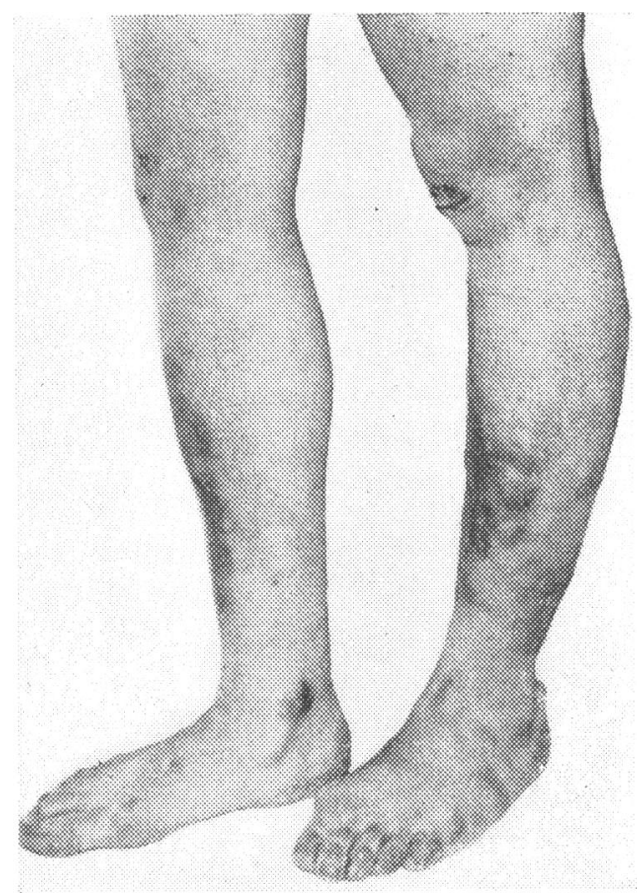

FIG. 3.-Scarring over knees and shins. Genu recurvatum and pes planus.

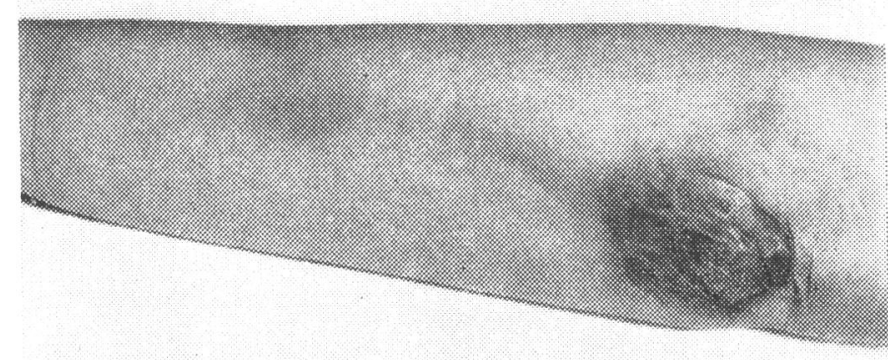

FIG. 4.-Pigmented atrophic scars over elbows. Ecchymosis on forearm.

\section{Case I}

\section{Gravis Type}

This 29-year-old man collapsed with severe chest pain when the airliner in which he was travelling suddenly lost its pressurization. He remained unconscious for three days, but ultimately made a complete recovery. Chest $x$-ray examination showed a widening of the ascending aorta. The finding of this abnormality, which had not been present previously, supported the diagnosis of dissection of the aorta. He had been born prematurely, and skin-splitting on minor trauma had always been troublesome. Frequent falls occurred in infancy, owing to unstable joints, and recurrent dislocation of the shoulder had eventually necessitated operation.

He was of slight stature, with many gaping scars on his forehead, elbows, and knees. His skin was hyperextensible, and he had marked generalized joint hypermobility. His ears were low-set, his nose was crooked, and epicanthic folds were present. He had prominent varicose veins, and there was a considerable degree of static pes planus.

His parents and siblings were all normal, but his daughter, who had been born prematurely, had similar stigmata.

\section{Case II}

This 36-year-old storeman was admitted to hospital with a painful swelling in the thigh which had occurred in the absence of any precipitating factor. A diagnosis of bleeding due to arterial tear was made, and as he was known to have the Ehlers-Danlos syndrome operation was considered to be inadvisable. He was treated with blood transfusion, and made a satisfactory recovery.

He had been born prematurely, and had always experienced bruising and skin-splitting on minor trauma. Orthopaedic treatment had been required for sprains of his ankles and knees, and he had skin-grafting to both elbows. Closure of lacerations had been difficult because of the tendency of stitches to tear out of the skin, and a surgeon had told him that "suturing his skin was like sewing cold porridge."

He was of average height, but very thin, with hardly any subcutaneous fat. There was pronounced hyperextensibility of the skin, which on release sprang back to its former position. All the joints were hypermobile, and the bony prominences were covered with wide scars. Thoracolumbar kyphoscoliosis was present, and the thorax was asymmetrical.

His parents and relatives were unaffected, and he had neither siblings nor children.

\section{Case III}

\section{Ecchymotic Type}

This 53-year-old housewife's life had been overshadowed by episodes of bleeding. The slightest trauma caused massive ecchymoses, and even housework led to bruising of the fingers. Spontaneous haematomata occurred in the muscles, and nose bleeds and menorrhagia had been features of her youth. Tooth extraction had been followed by haemorrhage which had necessitated suturing of the gums, and haemoptysis occurred during exacerbation of her chronic bronchitis.

Owing to her small stature her two children had been delivered by caesarean section. Both of these operations were complicated by heavy bleeding. On the second occasion she was unconscious for five days after the operation, and this episode was followed by a transient left hemiplegia. Appendicectomy and repair of a strangulated inguinal hernia were made difficult by the friability of the tissues, and bleeding and wound dehiscence occurred eight days after the former operation.

She was only $4 \mathrm{ft} .10 \mathrm{in}$. (147 cm.) tall, but her bodily proportions were normal. Her skin was thin and fragile, and the bony prominences bore atrophic pigmented scars. The skin was not hyperextensible, and the joints were not hypermobile. Varicose veins were present, and the teeth were irregular, while a loud systolic murmur was heard in the aortic area.

Her father and a brother and a sister had similar stigmata, and they had all died suddenly. Her father died in the street from a massive haematemesis, while her brother's death had been due to a perforated bowel which occurred when he jumped off a chair and landed on his heels. Her sister died in her 'twenties from a "heart attack," which was possibly a dissection of the aorta. However, her other siblings, together with her sons and their offspring, were all normal.

\section{Case IV}

This 37-year-old housewife was awakened by a severe abdominal pain. Internal bleeding was diagnosed, and in spite of transfusion she died a few hours later. Necropsy revealed a torn internal iliac artery and a retroperitoneal haematoma. She had previously spent a strenuous day playing with her children, but there were no other factors to account for the arterial lesion.

She had a lifelong tendency to spontaneous bruising, and her skin had been unusually fragile. Complete perineal tears had occurred at the deliveries of her two children, and she had had an operation to close a fistula between the right internal carotid artery and the cavernous sinus. The internal carotid was later ligated for recurrence of the fistula. Hysterotomy for termination of pregnancy was complicated by tissue friability and haemorrhage, and hysterectomy was performed. In the year preceding her death Ehlers-Danlos syndrome was diagnosed after a laparotomy for abdominal pain had revealed bleeding from dilated blood vessels in the abdominal wall. 
The patient had been slim but of average height, and arachnodactyly was present. Her skin was unusually thin, and there were pigmented atrophic scars over her elbows. The skin was somewhat lax, but it did not spring back to take up its former position after it had been stretched. Joint hypermobility was present, but this was not a prominent feature.

She had no siblings, and neither her children nor her parents were affected by the condition.

\section{Discussion}

A review of the world literature revealed no fewer than 15 reports of death in the Ehlers-Danlos syndrome, and in many of these reports descriptions of the clinical stigmata were also given. Brief summaries of the salient features of these cases are given in the Table.

There have been several reports of vascular or gastrointestinal emergencies in patients who ultimately survived (Rybka and O'Hara, 1967 ; André et al., 1965). However, a number of affected relatives of other patients have died from similar episodes (Jacobs, 1957 ; Barabas, 1967).

Including the present series, about 400 cases of EhlersDanlos syndrome have been reported. Over 20 of these patients died suddenly, and it is therefore apparent that patients with the syndrome are at a considerable risk. However, it is difficult to assess the magnitude of this risk, as obviously many uncomplicated cases remain undiagnosed or are never reported.

The patients in whom these events occurred appear to be of two distinct types, with recognizable clinical features. One group, with the gravis form, typified by Cases I and II and Cases 3,5 , and 6 in the Table, had a marked degree of joint mobility, skin extensibility, and scarring, in addition to varicose veins and various musculoskeletal deformities.

The other group of patients, with the ecchymotic variety of the Ehlers-Danlos syndrome, had minimal skin extensibility and joint hypermobility, but had a marked bruising tendency.
Cases III and IV had this form, and it is probable that Cases $1,2,9$, and 14 in the Table were similarly affected.

Several other previously reported patients had arachnodactyly, shortness of stature, and tissue friability (Cases 4, 11, and 15). These patients might have had the ecchymotic type, but it is possible that they represent a further variety of the Ehlers-Danlos syndrome which has not yet been delineated.

Of the present series 32 had the gravis, while four had the ecchymotic form. It is likely, therefore, that the risks of arterial complications are of moderate degree in the former group, while in the latter group the risks are very high indeed. The high death rate of the ecchymotic patients probably explains the rarity of this type of Ehlers-Danlos syndrome.

The cause of these arterial episodes is unknown, but histological abnormalities in the walls of blood vessels have been reported to be present (Rubinstein and Cohen, 1964). It is possible that connective tissues which support the blood vessels may be abnormal, and in addition a coagulation defect may be present (Lisker et al., 1960 ; Goodman et al., 1962). The basic defect of the Ehlers-Danlos syndrome is still a matter for speculation, but an abnormality in the binding of the fibrils which make up the collagen bundles has been postulated (Jansen, 1955).

The delineation and recognition of these types of the EhlersDanlos syndrome are of importance from the point of view of prognosis, not only for the patient but also for the affected progeny. These forms of the condition are transmitted by the autosomal dominant mode of inheritance, and any child of an affected parent, irrespective of sex, is at a $50 \%$ risk of being affected. These facts have a bearing on genetic counselling and on the assessment of a patient for possible termination of pregnancy.

My thanks are due to Dr. M. Gumpel for his constructive comments during the preparation of this paper. I am grateful

Death in the Ehlers-Danlos Syndrome

\begin{tabular}{|c|c|c|c|c|c|c|}
\hline $\begin{array}{l}\text { Case } \\
\text { No. }\end{array}$ & Author & $\begin{array}{c}\text { Age } \\
\text { at } \\
\text { Death }\end{array}$ & Sex & Cause of Death & Family History & Phenotypic Features \\
\hline 1 & Mories (1960) & 15 & $\mathbf{M}$ & Fell from bicycle. Haematoma in thigh. Death & & Thin papery scars over patella. Hyperextensible \\
\hline 2 & $\begin{array}{l}\text { Lapayowker } \\
\text { (1960) }\end{array}$ & 35 & $\mathbf{M}$ & $\begin{array}{l}\text { Acute regional enteritis diagnosed at laparo- } \\
\text { tomy. Death postoperatively following wound } \\
\text { dehiscence and gastrointestinal bleed }\end{array}$ & & $\begin{array}{l}\text { Multiple "cigarette paper" scars. Moderate } \\
\text { hyperextensibility of finger joints. Ecchy- } \\
\text { motic areas on feet }\end{array}$ \\
\hline 3 & $\begin{array}{l}\text { McFarland and } \\
\text { Fuller (1964) }\end{array}$ & 12 & $\mathbf{M}$ & $\begin{array}{l}\text { Death following a bleed into the popliteal } \\
\text { space. Two similar previous bleeds }\end{array}$ & $\begin{array}{l}\text { Elder brother and sister had } \\
\text { loose skin and mobile joints }\end{array}$ & $\begin{array}{l}\text { Many lacerations and dislocations. Multiple } \\
\text { gaping scars over elbows and knees. Skin }\end{array}$ \\
\hline 4 & $\begin{array}{l}\text { McFarland and } \\
\text { Fuller (1964) }\end{array}$ & 17 & $\mathbf{M}$ & $\begin{array}{l}\text { Death from bleeding into superior medias- } \\
\text { tinum due to spontaneous rupture of right } \\
\text { subclavian artery }\end{array}$ & Two normal sisters & $\begin{array}{l}\text { Bruising and excessive bleeding from minor } \\
\text { cuts. Scars over bony prominences. Hyper- } \\
\text { extensible joints. Possible arachnodactyly }\end{array}$ \\
\hline 5 & $\begin{array}{l}\text { Rubinstein and } \\
\text { Cohen (1964) }\end{array}$ & 47 & $\mathbf{F}$ & $\begin{array}{l}\text { Cerebrovascular accident due to carotid } \\
\text { aneurysm. Death } 3 \text { days after craniotomy } \\
\text { and ligation }\end{array}$ & $\begin{array}{l}\text { Father and brother had loose } \\
\text { ioints, scars, and extensible } \\
\text { skin. Her affected baby died } \\
\text { at age } 2 \text { from "congenital } \\
\text { cardiac lesion" }\end{array}$ & $\begin{array}{l}\text { Gross generalized hypermobility. Marked skin } \\
\text { extensibility and splitting, with multiple wide } \\
\text { scars }\end{array}$ \\
\hline 6 & $\begin{array}{l}\text { Lynch et al. } \\
\text { (1965) }\end{array}$ & 14 & $\mathbf{M}$ & $\begin{array}{l}\text { Death fr. } m \text { dissected aneurysm. Necropsy } \\
\text { showed aortocaval and internal iliac arterio- }\end{array}$ & Father, three brothers, and one & $\begin{array}{l}\text { Hypermobile joints. hyperelastic skin with a } \\
\text { bruising tendency, and slow healing }\end{array}$ \\
\hline 7 & $\begin{array}{l}\text { Kashiwagi et al. } \\
\text { (1965) }\end{array}$ & 64 & $\mathbf{M}$ & $\begin{array}{l}\text { venous aneurysms present } \\
\text { Death after repeated bleeding from colonic } \\
\text { diverticula }\end{array}$ & tion in stigmata & Hyperextensible fragile skin. Bruising tendency \\
\hline 8 & Graf (1965) & 24 & $\mathbf{F}$ & $\begin{array}{l}\text { Death from ruptured wall of left ventricle. } \\
\text { Previous bleeds from carotid cavernous } \\
\text { fistula. Necropsy showed multiple arterial }\end{array}$ & $\begin{array}{l}\text { Several members of family had } \\
\text { bleeding tendency }\end{array}$ & $\begin{array}{l}\text { Easy bruising. Bleeding from gastrointestinal, } \\
\text { urinary, and respiratory tracts. Transparent } \\
\text { extensible skin. Hypermobile fingers }\end{array}$ \\
\hline 9 & $\begin{array}{l}\text { Bannerman et } \\
\text { al. (1967) }\end{array}$ & 43 & $\mathbf{F}$ & $\begin{array}{l}\text { aneurysms } \\
\text { Death from ruptured splenic crtery. Left } \\
\text { common carotid ligated } 5 \text { years previously } \\
\text { for a carotid aneurysm. Necropsy showed }\end{array}$ & $\begin{array}{l}\text { Brother had spontaneous left } \\
\text { carotid-cavernous fistula }\end{array}$ & $\begin{array}{l}\text { Thin skin with prominent venous network. } \\
\text { Skin not extensible.' Joints not hypermobile }\end{array}$ \\
\hline 10 & $\underset{(1966)}{\text { McKusick }}$ & 15 & $\mathbf{M}$ & $\begin{array}{l}\text { multiple aneurysms } \\
\text { Thrown to ground. Death from dissection of } \\
\text { aorta }\end{array}$ & $\begin{array}{l}\text { Mother died at age } 22 \text { from } \\
\text { "internal haemorrhage of }\end{array}$ & Many scars. Cut easily and healed poorly \\
\hline 11 & McKusick & 24 & $\mathbf{M}$ & Death from dissection of renal artery & & Short stature. Arachnodactyly. Easy bruising \\
\hline 12 & McKusick & 14 & $\mathbf{M}$ & $\begin{array}{l}\text { Death due to dissection of thoracic and ab- } \\
\text { dominal aorta. Five previous episodes of }\end{array}$ & & Numerous scars on knees and ankles \\
\hline 13 & $\begin{array}{l}\text { Schoolman and } \\
\text { Kepes (1967) }\end{array}$ & 39 & $\mathbf{F}$ & $\begin{array}{l}\text { Death due to tear of the ascending aorta dur- } \\
\text { ing angiography to investigate a carotid- } \\
\text { cavernous fistula. Previous spontaneous }\end{array}$ & $\begin{array}{l}\text { Mother died of cerebrovascu- } \\
\text { lar accident at age } 33 \text {. } \\
\text { Brother died of perforation }\end{array}$ & $\begin{array}{l}\text { Bruising tendency and hypermobile joints. } \\
\text { Severe perineal tear at childbirth. Histology } \\
\text { "typical of Ehlers-Danlos syndrome" }\end{array}$ \\
\hline 14 & Barabas (1967) & 30 & $\mathbf{F}$ & $\begin{array}{l}\text { Death due to spontaneous rupture of aorta. } \\
\text { Previous haematomata in right iliac fossa } \\
\text { and both popliteal fossae }\end{array}$ & $\begin{array}{l}\text { No family history of Bhlers- } \\
\text { Danlos syndrome }\end{array}$ & $\begin{array}{l}\text { Severe bruising tendency. Skin transparent, } \\
\text { with prominent venous network. Slight } \\
\text { hyperextensibility of skin. Hypermobility } \\
\text { limited to hands. Episodes of severe ab- }\end{array}$ \\
\hline 15 & Aldridge (1967) & 27 & $\mathbf{F}$ & $\begin{array}{l}\text { Death from perforated sigmoid colon. Similar } \\
\text { perforation } 2 \text { years previously }\end{array}$ & & $\begin{array}{l}\text { Thin scars. Arachnodactyly. Spina bifida. } \\
\text { Spondylolisthesis }\end{array}$ \\
\hline
\end{tabular}


to all those physicians who gave me information and allowed me to examine patients under their care.

This investigation was supported by grants from the Arthritis and Rheumatism Council and the St. Thomas's Hospital Endowment Fund. This study formed part of a thesis presented for the M.D. degree of London University.

\section{REFERENCES}

Aldridge, R. T. (1967). Brit. 7. Surg., 54, 22.

André, R., Duhamel, G., Vergoz, D., and Lavallée, R. (1965). Bull. Soc. méd. Hôp. Paris, 116, 971.

Bannerman, R. M., Graf, C. J., and Upson, J. F. (1967). Brit. med. F., 3,558 .

Barabas, A. P. (1967). Brit. med. F., 2, 612.

Beighton, P. (1968). Proc. roy. Soc. med., 61. In press.
Goodman, R. M., Levitsky, J. M., and Friedman, I. A. (1962). Amer. F. Med., 32,976

Graf, C. J. (1965). Arch. Neurol. (Chic.), 13, 662.

Jacobs, P. H. (1957). Arch. Derm., 76, 460.

Jansen, L. H. (1955). Dermatologica (Basel), 110, 108.

Kashiwagi, H., Riddle, J. M., Abraham, J. P., and Frame, B. (1965). Ann. intern. Med., $63,249$.

Lapayowker, M. S. (1960). Amer. 7. Roentgenol., 84, 232.

Lisker, R., Noguerón, A., and Sánchez-Medal, L. (1960). Ann. intern. Med., 53, 388.

Lynch, H. T., Larsen, A. L., Wilson, R., and Magnuson, C. L. (1965). 7. Amer. med. Ass., 194, 1011.

McFarland, W., and Fuller, D. E. (1964). (1964). New Engl. F. Med., $271,1309$.

McKusick, V. A. (1966). Heritable Disorders of Connective Tissue, 3rd ed., p. 179. St. Louis.

Mories, A. (1960). Scot. med. 7., 5, 269.

Rubinstein, M. K., and Cohen, N. H. (1964). Neurology (Minneap.), 14, 125.

Rybka, F. J., and O'Hara, E. T. (1967). Amer. F. Surg., 113, 431.

Schoolman, A., and Kepes, J. J. (1967). F. Neurosurg., 26, 82.

\section{Medical Memoranda}

\section{Hepatic Artery Aneurysm after Staphylococcal Endocarditis}

\author{
Brit. med. F., 1968, 3, 659-660
}

Mycotic aneurysms of hepatic arteries are a recognized though rare complication of bacterial endocarditis (Stengel and Wolferth, 1923). We here report the case of a woman with mitral incompetence who, after staphylococcal endocarditis, developed intrahepatic aneurysms of branches of the right and left hepatic arteries.

\section{CASE Report}

On 20 April 1967 a 40-year-old housewife known to have mitral incompetence was admitted to hospital after a small haematemesis. Clinical and barium-meal examinations were negative. She was thought to have developed an acute gastric erosion and was discharged on antacids.

In 1961 and in February 1967 she had been successfully treated with antibiotics for acute staphylococcal endocarditis with peripheral embolic features, including, on the second occasion, splinter haemorrhages and a left homonymous hemianopia.

During the next two months she began to have increasingly frequent episodes of upper abdominal pain, sometimes with haematemesis, melaena, and passage of dark urine. These led to her readmission as an emergency case on 22 June.

On abdominal examination the only abnormality was marked epigastric tenderness. A repeat barium-meal examination and gastroscopy showed no lesion, but she continued to have abdominal pain and melaena. After two days her gall bladder became palpable and she developed transient obstructive jaundice. Intravenous cholangiography failed to outline the biliary tract.

Laparotomy was performed (by J.T.R.) on 30 June. The gall bladder and common bile duct were found to be distended with blood clot. The hepatic arteries and the other abdominal viscera (including stomach and duodenum, which were opened) were normal. No lesion or active bleeding was found in the biliary tract following exploration and operative cholangiography. The gall bladder was excised and the common duct drained with a $\mathrm{T}$ tube. Because of the patient's poor condition the operation was then terminated.

A coeliac angiogram, performed four days later, showed an aneurysm, $2.5 \mathrm{~cm}$. by $8 \mathrm{~mm}$., arising from a branch of the right hepatic artery (see Fig. 1). A second laparotomy was therefore carried out by Miss D. Nightingale on 13 July.

The right and left hepatic arteries were found to arise from a common trunk just above the first part of the duodenum. A study of the preoperative coeliac angiogram suggested that the larger and more posterior vessel was the right hepatic. This vessel was cannulated and its distribution to the right lobe of liver was confirmed by operative angiography. It was then triply ligated in continuity, the middle ligature transfixing the artery. The abdomen was closed, leaving the $\mathrm{T}$ tube in situ.

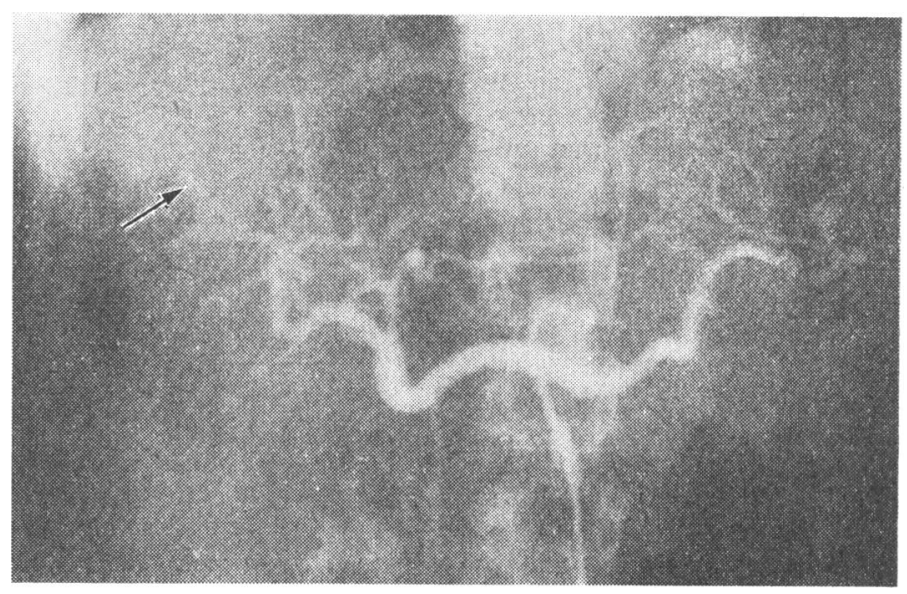

FIG. 1 - Coeliac arteriogram showing aneurysm of a branch of the right hepatic artery (arrowed), 4 July 1967.

Her postoperative course was uneventful. The $T$ tube drained clear bile. There was a slight rise in the serum bilirubin, a fall in the previously raised alkaline phosphatase, and slightly delayed bromsulphalein excretion but no other significant changes in her liver-function tests. A liver scan on 3 August was normal. On discharge on 6 August she was well and had had no further abdominal pain.

During the next six weeks altered blood was discharged from the wound on several occasions and she required blood transfusions. There was no further gastrointestinal bleeding.

Her last admission was on 17 September, and the wound sinus closed shortly afterwards. At that time her liver-function tests (see Table) and her bleeding-time and clotting-time were normal. A further coeliac angiogram on 22 September showed a small 